\title{
Institutionalization of Small Business Similar Products in Umbulharjo Sub-District
}

\author{
Supardal* and Sri Utami \\ Science Government Department, STPMD “APMD” Yogyakarta, Indonesia \\ *gusdal66@gmail.com
}

\begin{abstract}
Model-based Small Micro Economy (SME) network classifier similar products are SMEs with similar products, so that synergizes the potential well in the capital, the process of production and in the marketing of SME products, while reducing unhealthy competition between players. The results of the study in the District Umbulharjo formed group of SMEs engaged in batik and jumputan, so the development of SMEs is quite good and can compete with products from other regions. In the development of the SME group engaged in batik and fabric jumputan still facing problems related to human resource capabilities of SMEs in entrepreneurial management. Another problem arises competition between groups, especially in the determination of the standard price of each product SMEs, resulting in price competition between groups. Therefore, in this study focuses on strengthening SMEs, developing relationships with the SME group market, provision of material and financial institutions. Furthermore, building a kind of container or community group batik jumputan and fabric, so it becomes a sort of center or central batik and fabric jumputan Umbulharjo district.
\end{abstract}

Keywords: Network of SME, Society, Relationships, Markets, Banking

\section{Introduction}

Micro Small Business (SME) is always interesting to be discussed, because this effort is mostly cultivated by the community. It is related to the fact that the government / local government faces the limitations to create formal employment, so the work of the informal sector helps the government to solve the problem of power - this work. The informal sector employment is small and micro enterprises (SMEs), because this sector has been able to create employment opportunities for all age groups, all education and working groups are not bound by time. Given the SME sector's strategic, the government should have initiatives and commitments to develop this sector.

There are growing concerns about poverty rising with high unemployment, both open and disguised unemployment. It is estimated that as many as 42.5 million unemployed in Indonesia, plus 2.5 million people who will enter the work field every year. Indonesia's economic growth of only about $5 \%$ has not been able to absorb the entire new workforce, at least it needs $8 \%$ growth to absorb the entire new workforce. Economic growth in the coming years is not yet bright. Therefore, the development of SMEs is also seen as a strategy to reduce unemployment and poverty.

Therefore, the economic development strategy needs to be reorganized towards the development of the populist economy, including SMEs. Economic empowerment of the people

Article history:

Received (December 21, 2019), Review Result (January 26, 2020), Accepted (April 5, 2020) 
demands the readiness of all parties concerned, to continuously strive to improve both technical and non-technical skills. At this time and the future, economic empowerment of the people (in this case SMEs) through business collaboration with a strategic alliance system is a healthy and competitive needs absolutely essential for the nation of Indonesia. So economic activity in the present time should be driven by a people economy that includes SMEs including cooperatives and entrepreneurship

From the results of previous research, found model of network of perpetrators of SMEs based on similar products in the District of Umbulharjo Yogyakarta City, namely the group Batik JenggoloPandeyan and group Batik JumputanTahunan (BJB). Fuschi et al, in [1] Network model of SMEs based on similar products is a form grouping of SMEs who have similar products, so as to synergize the various potentials of SMEs. The benefits of networking SMEs based on similar products will be able to strengthen capital, improve production processes and expand the market [2]. Besides, this model is also formed based on the aspirations of the community (grassroots), so the level of sustainability is quite high, compared to the grouping model of SMEs by the government in channeling capital assistance. For that in the future can be used as a model of government policy in grouping the actors SMEs.

The next step is to increase the productivity of SMEs group of this kind of product by developing relationship model with third party such as; market parties, financial institutions and raw material providers. At the stage of reviewing efforts to build a good SME network with third-party suppliers of raw materials, the market, financial institutions, the government as policy makers, and large industries in the frame of partnership. Ultimately the development goal of SMEs in order to compete and play with the global market that continues to enter our domestic market.

Populist economy which is the economic base of Indonesia, has great potential to enter the global market if it can be developed consistently and sustainable. Uniqueness and product uniqueness of the creative hands of small entrepreneurs is the basic capital of national economic development of high value and needs to be developed. That is, efforts to empower the people's economy including SMEs should consider also the dynamics of global markets. Because of the future developments in the free-market framework, it must be dealing with free market players, including global economic actors, for that is the need to prepare SMEs early on before entering the global market.

The scope of SMEs (Small Micro Business) which refers to the Law No.20 of 2008, namely: Determination of SMEs criteria so as to obtain market share, grouping of micros, small and medium enterprises is based on the amount of credit ceiling approved by banks. Micro business group of credit amount up to Rp. 50 million, small group between Rp. 50 million to Rp. 500 million, medium group sedangka between Rp. 500 million up to RP. 5 billion, so the amount of credit up to Rp. 5 billion is the entry of the group or category of SME. Thus, amount of credit above Rp. 5 billion including large business group. Criteria of SMEs according to Law no. 20 Year 2008.

According to Alam in [3], the concept of economic empowerment can be summarized as follows: First, People's economy is an economy organized by the people. The economy organized by the people is a national economy rooted in the potential and power of society widely to run the wheels of their own economy. The notion of the people is all citizens; secondly, the empowerment of the people's economy is an attempt to make a strong, big, modern and highly competitive economy in the right market mechanism. Because the constraints of people's economic development are structural constraints, the people's economic empowerment must be done through structural change; third The structural change in question is the shift from the traditional economy to the modern economy, from a weak economy to a strong economy, from 
a subsistence economy to a market economy, from dependence to self-reliance. The steps of the process of structural change include: resource allocation of resources empowerment, institutional strengthening, technological mastery, human resource empowerment; Fourthly, the empowerment of the people's economy, not only by increasing the productivity, giving the capital injection as a stimulant, but must be ensured the close cooperation and partnership between the developed and the still weak and undeveloped; Fifth, its policy in the empowerment of the people's economy is: the provision of opportunities or greater access to production assets (especially capital), strengthening the position not merely price taker, education and health services, strengthening small industries, encouraging the emergence of new entrepreneurs; and spatial equalization; Sixth, community empowerment activities include: increased access to business capital assistance, increased access to human resource development, increased access to facilities and infrastructure that directly support socioeconomic local communities.

In this context, community empowerment must be carried out through three main aspects: First, creating an atmosphere or climate that enables the development of enabling potential or power. Here the starting point is the recognition that every human being, every society has the potential to be developed. Empowerment is an effort to build that power, by encouraging (encouraging), motivating and awakening awareness of its potential, and striving to develop it; second, to strengthen the potential or power of the community (empowering) through the provision of inputs in the form of funding, infrastructure and facilities development, physical (road, irrigation, electricity) and social (school, health), as well as the development of funding, research and marketing institutions in Regional, and opening access to various opportunities (opportunities) that will make people more empowered; thirdly, empowering also contains the sense of protecting the community through favor of a weak society to prevent unbalanced competition by lack of empowerment against the strong, and not to isolate or mask the interaction. Community empowerment does not make the community dependent on various charity programs, because basically every enjoyment must be generated on its own, which results can be exchanged with others.

Empowerment is needed to improve people's bargaining position by increasing their capacity. There are at least three basic capacities needed for it, namely:

First: the voice, access, and control of citizens against government and development that affect their daily lives. First, votes are the rights and actions of citizens to convey their aspirations, ideas, needs, interests and demands to their nearest community and government policy. The goal is to influence government policy as well as to set a common agenda for managing life collectively and independently.

In the context of participatory development planning, the voice can be communicated by the community through the deliberations of development planning. It is here that people can propose development ideas that depart from their real needs, prioritize, and make development decisions. However, the development system with the top down paradigm in the past has reduced the capacity, so that people feel hesitant or do not dare to express their ideas in official forums although given the opportunity. Here is needed a learning process through facilitation, motivation, education, and advocacy continue to take care to restore the confidence of the community and improve its ability to convey aspirations clearly and systematically based on needs.

Second, access means space and community capacity to enter into the arena of governance, which influences and determines the policy and is actively involved in managing public resources including public services. Access will be the meeting point between citizens and government. The government is obliged to open up citizens' access space and provide public 
services to citizens, especially marginalized groups. Instead, the villagers jointly proactively identify their problems, needs and potentials as well as formulate the idea of problem solving and systematic potential development. The government is obliged to respond to the idea of citizens so that it can formulate a shared vision and policy with a foundation on partnership and trust.

Third, the control of citizens against their community environment and political processes associated with the government. We recognize internal control (self-control) and external control. This means that control not only includes the capacity of the community to monitor (monitor) policies (implementation and risks) and government actions, but also the ability of citizens to assess critically and reflectively on the risks of their actions. Self-control is very important because people have long been in the context of chain oppression: the upper one oppresses the bottom, while the lower one oppresses each other to the side. This means that external controls are used by society to combat exploitation from above, while self-control is intended to avoid the chain of peer oppression, while building social responsibility, commitment and citizen competence to everything that affects their daily lives.

Leopold von Wiese and Howard Becker see the institution from the point of its function. According to them, social institutions are defined as a network of processes of human relationships and between groups of people that serve to preserve those relationships and patterns, in accordance with the interests of people and groups. In addition, a sociologist named Summer sees societal institutions from a cultural point of view. Summer defines social institutions as actions, ideals, and attitudes of culture, which has an eternal nature and which aims to meet the needs of society. Therefore, the existence of social institutions have a function for social life. These functions include: first, Provide guidance to community members about attitudes in dealing with problems in the community, especially those concerning basic needs; second, maintaining the integrity of the community concerned; third, to give the community members the ability to exercise control over the conduct of their members.

Thus, the social institution is a set of procedures and procedures designed to regulate human relationships in social life. Therefore, social institutions are present in every society either simple society or modern society. This is because every society wants organizational life order established by a group of people certainly have a reason. An expert named Herbert G. Hicks presents two reasons why people choose to organize: a. Social reason (social reason), as "zoon politicon" means creatures that live in groups, then people will feel important to organize for the association and meet their needs. This can be found in organizations that have intellectual, or economic targets. The reason material (material reason), through the aid of human organization can do three things that can not be done alone: first, it can enlarge its ability; second, it can save the time it takes to achieve a goal, through the help of an organization; third, can benefit from the knowledge of previous generations that have been collected.

This study is the strengthening of socio-economic association associated with the formation of community-based SME networking in the District Umbulharjo, so that it can strengthen the institutional SMEs. With the strengthening of institutional SMEs through this technical guidance will in turn strengthen the bargaining position of SMEs in the face of global market competition.

The rest of this paper is organized as follow: Section 2 describes the research method. Section 3 presents the result and following by discussion. Finally, Section 4 concludes this works.

\section{Research methods}


In carrying out research on this community using adult learning methods, because the participants are SMEs actively joined in the community of SMEs based nextwork similar products in District Umbulharjo. The participants already know the process of organizing in the forum of the community of SMEs, so that in the process of technical guidance and training a lot of sharing and discussion about various issues and problems in the community. Furthermore, the speakers convey the material needed by the perpetrators of UGM who are incorporated in the paguyuban. Thus it is expected that the material presented by the resource person can help solve the problems that arise in the paguyuban. Furthermore, the devotees also directly conduct monitoring in SMEs business group batik jumputan cloth to evaluate whether technical guidance has been understood and also implemented by groups of SMEs who are members of the community of SMEs.

\section{Results and discussion}

The following descriptions will be presented on the results of the study of dedication and simultaneously discussed the performance and capacity of SME actors in Umbulharjo subdistrict of Yogyakarta after receiving training and technical guidance on institutional strengthening of SMEs.

From a series of results of the impact assessment of technical guidance is related to the performance and capacity of SMEs in the district Umbulharjo Yogyakarta, has formed a lot of Regional Economic Development Forms or PEW in some urban villages in the district Umbulharjo. Like, the SME group model established on the initiative and local wisdom of SMEs based on similar products as follows:

SME group "KainJumput 12", this SME group consists of members of RW 12 Pandeyan Village, amounting to 15 people housewives. This SME group has been quite smoothly in its business, has started to receive orders for school uniforms, uniforms PKK mothers sub-district and some community market demand around the production house means the demand for new markets to the local market in one district. Training and facilitation was held from PT ISI Yogyakarta. What is interesting about this group of SME players is the spirit or greget members, because with their own capital is still very limited but has been able to make batik. The development of SME group "KainJumput 12" is quite encouraging, because the formation of this SME group is based on an awareness or initiative from members about the importance of grouping in similar products to strengthen their business. As for the problem is the lack of capital and marketing assistance with Online system. This business group needs to be facilitated by the government, starting from group strengthening, capital assistance and design development, as well as assisting in market access or by online system.

Group of SMEs "Batik and JumputanBatikan" (abbreviated BJB) in the village of BatikanTahunan village. This group consists of 14 people consisting of mothers RT of Umbulharjo Yogyakarta Urban Village. This SME group has been assisted by LPMK Kelurahan Annual, mentoring from KPMP Yogyakarta city, for 3 consecutive year since know 2012 until 2014 get help from Disperindagkoptan DIY, often exhibition to Bandung, Jakarta and Yogyakarta area. This SME group has a regular meeting held every month on the 25th. SME group "BJB" is quite existent and productive in producing batik jumputan work that is very distinctive that is different from other batik works. Means to market the product (showroom) is already owned by this SME group, so that not infrequently tourists from inside or outside many who come to just look around or buy batik products are marketed.

Compared to other business groups, this group of SMEs "BJB" is more advanced, because this SME group already has an AR / ART that is used as a base and a mechanism in sharing 
profit for its members, so it is very clear the rules of the game (management) it runs. To conduct group and member evaluation, then every month there is a member meeting forum, the event is done in an effort to strengthen organizational soul and entrepreneurship of SME group.

SME group "Ibu Sejahtera" located in Kampung Celeban RT 12. SMEs "Ibu Sejahtera" This business group is engaged in batik and jumput. The first group of SMEs was formed by its members there are 15 senior mothers who have relatively free time, which is now the development of the number of members has reached 25 members. This SME group starts from scratch, both from the skills possessed by members and from the capital side. But the members of the SME group is very persistent and the spirit to move forward together, every month there is a scheduled meeting of members ie every 20th. The place of marketing of the product or showroom has 2 pieces and internet facilities also exist, only need to develop the ability in its use to be more skilled. The strength of this business group attracted the government to provide assistance to the perpetrators or members of 25 people with the assistance of each 1 million in the framework of Regional Economic Development (PEW). With this assistance the roles of members have enough capital to expand their business which can then be marketed through their business group using the facilities they already have together. Nevertheless, the SME group "Ibu Sejahtera" expects to be trained and facilitated in solving the constraints (especially financial management of money inflows / outflows), so that this effort will become more advanced and smooth which in turn the welfare of members becomes more increased

SME group "Dea Modis". This group of SMEs Jumputan do a lot of coaching / training to the community around the production house. In the process of producing this small group of SMEs use labor from members of the community who live nearby (especially the younger generation). However, once the training has been completed, the condition that has been built is not sustainable (that is, the willingness and spirit of the community to cultivate this activity is very low), so that the design products that have been taught become the products of other SMEs. As a result, when this SME group there are orders (orders from buyers) that many difficult to be fulfilled due to limited human resources. Similarly, other constraints faced by these SMEs are related to financing and marketing of production in addition to other human weaknesses. The dynamics of SME development in Umbulharjo sub district is good enough after the training and technical guidance of entrepreneurship, but the SMEs grouping is not all based on similar products, because the level of diversity of SME products is very high variation, let alone between kelurahan one with another. There are some actors of SMEs that grouping based on forums of friendship between SMEs and the main purpose as a forum for friendship and the means to obtain information, has not lead to productive goals or product marketing. But there are also groupings of SMEs based on similar products and the desire to jointly develop their business together shoulder-to-shoulder starting from the determination of raw materials, production process and marketing of products carried out together in a group of SMEs and that is not less important information related to financial capital to develop their business

The purpose of government advocated the formation of groups because of the assistance program for the empowerment of SMEs, so the practice in the field there are many cases of fictitious groups that form a group because they only want to get help only, after the help is finished passively again no business activity. So in its development, although some of the actors of SMEs in the formation of groups only as a forum of friendship and get facilities from the government, but some SMEs are very aware that the formation of similar product-based group is very good to do, even though the practice is very difficult to be realized (difficult).

To increase production, it is necessary to develop SME group relationships with third parties (financial institutions, markets and raw material providers). From the results of Focus Groups Discussion (FGD), that of the four groups of SME actors in Umbulharjo sub-district agreed to 
form a joint forum or some kind of association. In a joint forum as a forum for SME players in running their business based on similar products, because it can assist in the fulfillment of raw materials, production processes, especially in the development of designs and new motivations in accordance with market demand, access to finance or capital, unique and unique SME products.

In relation to the scheme of regional banking financing according to the characteristics of SMEs in the leading sectors, a special credit scheme is needed which enables SMEs to access optimal banking funds [4], therefore there needs to be a formulation of relationships between SMEs with the financial institution clearly and give certainty for SMEs. It is said Afrifa in [5], working capital in a company is very instrumental in running business activities to keep running smoothly and can achieve the expected goals. In response to the needs of SMEs for the importance of working capital, financial institutions (which in this study are BMT and BRI) as fund providers are obliged to provide credit schemes that can be accessed by SMEs in accordance with the interests and abilities of SMEs.

With technical guidance will improve the ability of UKM actors who are built together in a container group of SMEs based on similar products will be able to utilize facilities both bembankan and related to the market or marketing of SME products. Because with togetherness will be able to create a balance which in turn the motto "together to advance in the family economy, because the economic strength of the nation or state should start from the family's economic building through a joint-based business of similar products" can be realized, especially in the district Umbulharjo City Yogyakarta, so that SMEs based on similar products are really ready to compete in the global era.

From the sharing results in bimtek also known that there are still a small number of SMEs do not build network with providers of raw materials on a regular basis. Groups that already have relationships with raw material providers are large groups of SME financiers, consequently many other small SME actors are working with providers of raw materials as well as collectors of production. Thus there is still a dependence on strong SMEs, they suggest that each district established a kind of cooperative that is able to provide raw materials of production and simultaneously accommodate and channel production to the market, so as not to get caught in the circle of monopoly system by a powerful group. In its development has been pioneered the establishment of cooperatives by the Government of Yogyakarta, but until now can not be done

From the analysis of batik groups and jumputan with the three outer pillars of the microfinance institutions, the market / consumer and raw material suppliers, it can be developed mutually beneficial and sustainable relations as follows:

Table 1. Model development of SME relations with external parties

\begin{tabular}{|l|l|c|c|}
\hline & MicrofinanceInstitutions & $\begin{array}{c}\text { Supplier of Raw } \\
\text { Materials }\end{array}$ & Market / Consumer \\
\hline
\end{tabular}




\begin{tabular}{|c|c|c|c|}
\hline SME problem & $\begin{array}{c}\text { SMEs lack capital, but not all } \\
\text { of them can access the } \\
\text { capital in financial } \\
\text { institutions, because the } \\
\text { various conditions are not } \\
\text { fulfilledUKM lack of capital, } \\
\text { but not all can access capital } \\
\text { in financial institutions, } \\
\text { because the various } \\
\text { conditions are not met }\end{array}$ & $\begin{array}{c}\text { Not all UKM actors } \\
\text { can access raw } \\
\text { materials, except } \\
\text { SMEs that have been } \\
\text { big, until small SMEs } \\
\text { depend on them }\end{array}$ & $\begin{array}{c}\text { Perpetrators of SMEs can not } \\
\text { penetrate including the } \\
\text { international market, limited } \\
\text { domestic market only, even the } \\
\text { demands of malls and } \\
\text { supermarkets not all can fulfill. }\end{array}$ \\
\hline Potensi UKM & $\begin{array}{c}\text { SME actors are a potential } \\
\text { for financial institutions, } \\
\text { because the amount is large, } \\
\text { in contrast SME players can } \\
\text { strengthen their capital }\end{array}$ & $\begin{array}{c}\text { With good relations } \\
\text { with raw material } \\
\text { providers will ensure } \\
\text { business continuity of } \\
\text { SMEs }\end{array}$ & $\begin{array}{c}\text { With the entry of SME } \\
\text { products into the market, then } \\
\text { the perpetrators will be able to } \\
\text { increase production so that will } \\
\text { increase revenue }\end{array}$ \\
\hline The purpose \\
of SMEs
\end{tabular}

From mapping the development of relationship between SME group with third party (financial institution, market and raw material provider) can be given analysis as follows: Judging from the financial problems of SMEs, then for financial institutions is an opportunity, because it is precisely financial institutions are in need of many customers who need capital. Thus this relationship can be improved into a mutually beneficial and sustainable relationship. Because the more SMEs want to increase production, it will require a lot of capital, otherwise for financial institutions will also increase the level of credit that can be channeled. For that financial institution must be able to maintain the relationship by still providing trust and convenience for SMEs in channeling credit needed SME players. While the problem of SMEs related to the market, where the qualification of products for markets that have not met the market standard, then SMEs should be able to improve the quality of production process. So far, SME products are considered cheap products and careless, so less market demand, for the strengthening of human resources become the need to be able to compete in the global era. While the relation between SMEs and material providers, so far more raw material owners believe in big SMEs, so the future needs to be developed cooperative model to receive raw materials then distributed to small SME actors, so there is even distribution in distributing raw materials.

Analysis of Institutional Strengthening of Batik and JumputanUmbulharjo Group.Follow-up from the results of technical guidance, the SMEs from a number of groups of batik and jumputan agreed to strengthen the community pool or pool and Umbulharjo district. Paguyuban or central batik and jumputan this is a container that organizes batik groups and jumputan that exist in the District Umbulharjo. Thus there will be guarantees relating to production standards, price standards and also business management batik and jumputan, so as not to harm each other between SMEs players, unhealthy competition and business climate that is less conducive.

Umbulharjo UKM perpetrators especially engaged in batik and jumputan business have agreed to form a group of similar businesses, at least have formed 5 groups of batik and cloth 
jumputan. It is necessary to strengthen the capacity of SMEs so that each group does not walk alone, both in production process, marketing and price determination, so there is no unhealthy competition between groups. Therefore, each group agreed to strengthen some kind of paguyuban or central batik and cloth jumputan of UmbulharjoSubdistrict, as the only place for batik and cloth group of jumputan in UmbulharjoSubdistrict.

For this purpose, all groups agreed on the training and technical guidance of the STPMD service team: APMD "in order to strengthen the human resources of batik and cloth business players such as business management training, from production process to marketing problem is very important and need to be sustainable, so it is time to become the central business of batik and jumputan in Umbulharjo ready to receive visits from various tourists, both domestic, and foreign tourists who want to know, learn and batik shopping and jumputancloth.

\section{Conclusion}

First, From the implementation of training and technical guidance to the group of SMEs in the community batik jumputan network modeling SMEs based on similar products in the District Umbulharjo very helpful business groups batik and cloth jumputan. From a group of similar product-based businesses namely batik, it turns out that this group has a fairly good development and sustainability compared with the government-formed business group in order to distribute the assistance to any small business entrepreneurial background, which is important to form a group of 10 people and have business. However, this formation of government groups tends to be very fragile, because the group is active because of the pursuit of aid, after the aid is exhausted the business group is also disbanded and there is no sustainability.

Secondly, after Umbulharjo's batik and cloth group jumped to gain the strengthening of its human resources, it turned out that group problems were significantly reduced, such as production and marketing problems. However, there are problems related to human resource capability, especially regarding the management of their business. Since most SME actors have not been able to manage financial management, marketing and production, so in the business tends to still be home or family and impressed side job. In the case that this can be well managed this effort can be a staple job that can absorb labor. Because facing the era of global market forward batik and cloth business jumputan have good prospect.

Third, After each business group based on similar products, in this case batutan business and cloth jumputan running well, but raises the problem that intersect between groups. So after each group of batik and cloth business jumputan develop with each have market segment, but happened price competition between group, so price competition is not healthy. In such conditions sometimes disappoint the buyers who in fact tourists both domestic and foreign. For that it would need a kind of standard price between groups will be various types of batik and kainjumputan which is a typical feature of SME products UmbulharjoSubdistrict, for that emerged the recommendation of the need for assistance to the community UMK UmbulharjoSubdistrict.

Fourthly, in evaluating the implementation of institutional strengthening of SME players, SME players are needed to strengthen the capacity of SME actors related to business management, financial and SME quality. This is apparent in discussions during training that have never received such material. So far, the hampering of business by SMEs is the low capacity of SMEs management. Therefore, it is agreed with the devotees to conduct technical guidance for the strengthening of perpetrators of SMEs in a sustainable manner, so that SMEs are able to increase production with the standard quality required by the market. In the end will 
be able to increase the incomes of the citizens engaged in the field of small micro production, so that ultimately increase the welfare of citizens.

\section{References}

[1] D. L. Fuschi and M. Tvaronavičienè, "A network based business partnership model for SMEs management," Entrep. Sustain. Issues, vol.3, no.3, pp.282-289, (2016) DOI: 10.9770/jesi.2016.3.3(5).

[2] D. Vannoni, "The impact of formal networking on the performance of smes," In: Proceedings of International Academic Conferences. International Institute of Social and Economic Sciences, (2019) DOI: 10.20472/iac.2018.035.046.

[3] H. A, I. A. Alam, H. Dunan, and H. A, "MSMEs empowerment and development strategy model," J. Adv. Res. Dyn. Control Syst., vol.8, pp.324, (2019), DOI: 10.5373/jardcs/v11i12/20193209.

[4] M. Nayak, "The impact of commercial bank's characteristics on micro, small, and medium enterprises in India," Econ. J. Emerg. Mark., vol.9, no.1, pp.1, (2017), DOI: 10.20885/ejem.vol9.iss1.art1.

[5] G. A. Afrifa and K. Padachi, "Working capital level influence on SME profitability," J. Small Bus. Enterp. Dev., vol.23, no.1, pp.44-63, (2016), DOI: 10.1108/JSBED-01-2014-0014. 